\title{
Minat Mahasiswa Dalam Investasi Di Pasar Modal
}

\author{
Syaeful Bakhri \\ Fakultas Syariah dan Ekonomi Islam \\ IAIN Syekh Nurjati Cirebon \\ Email : sultan01aulia@yahoo.com
}

\begin{abstract}
Abstrak
Merujuk data Kustodian Sentral Efek Indonesia (KSEI), jumlah investor pasar modal Indonesia sampai dengan Maret 2018 mencapai 1,21 juta single investor identification (SID), naik 36 persen dari realisasi 2016 sebanyak 894.116 SID. Kenaikan dua digit tidak membuat jumlah investor dinilai signifikan bila dibandingkan dengan jumlah 260 juta penduduk Indonesia. Mahasiswa sebagai agent of change memiliki peran yang sangat strategis dalam melakukan sosialisasi informasi mengenai investasi di pasar modal. Penelitian ini bertujuan untuk melihat respon dan mengukur minat mahasiswa Fakultas Syariah dan Ekonomi Islam IAIN Syekh Nurjati Cirebon dalam melakukan investasi di pasar modal.Beberapa hal yang bisa dilihat dan mempengaruhi minat mahasiswa dalam melakukan investasi adalah manfaat investasi, nilai tambah investasi dan kondisi ekonomi. Sampel dari penelitian ini adalah 96 mahasiswa Fakultas syariah dan ekonomi Islam IAIN Syekh Nurjati Cirebon.

Hasil penelitian ini menunjukkan bahwa tidak adanya hubungan antara manfaat investasi dengan minat berinvestasi pada mahasiswa IAIN Syekh Nurjati Cirebon, dibuktikan dengan nilai $(p=0,336>0.05)$. Hasil analisis juga menggambarkanbahwa tidak ada hubungan antara nilai tambah dan minat berinvestasi pada mahasiswa IAIN Syekh Nurjati Cirebon, sebagaimana dibuktikan berdasarkan nilai $(p=0.574>0.05)$. Variabel kondisi ekonomi mahasiswa dengan minat investasi pada mahasiswa IAIN Syekh Nurjati Cirebon ternyata juga tidak memiliki hubungan, dibuktikan berdasarkan hasil ( $p=0,619>0.05$ ).

Investasi bagi mahasiswa adalah sebuah proses pembelajaran dalam rangka mempersiapkan diri dalam membangun kehidupan ekonomi baik secara pribadi maupun. keluarga. Upaya peningkatan sosialisasi yang terus menerus harus tetap dilakukan, karena bagaimanapun pasar modal merupakan salah satu pintu bagi proses belajar mahasiswa tentang ekonomi dan investasi.
\end{abstract}

Kata kunci :Manfaat Investasi, Nilai Tambah, Kondisi Ekonomi dan Minat Investasi dan Pasar Modal

\begin{abstract}
Referring to the data of Kustodian Sentral Efek Indonesia (KSEI), the number of Indonesian capital market investors up to March 2018 reached 1.21 million single investor identification (SID), up 36 percent from 2016's realized 894,116 SID. A double-digit increase does not make our investors significant when compared to 260 million Indonesians. Students as agent of change have a very strategic role in disseminating information about investment in capital market. This study aims to see the response and measure the interest of students of the Faculty of Sharia and Islamic Economics IAIN Syekh Nurjati Cirebon in investing in the
\end{abstract}


capital market. Some things that can be seen and affect the interest of students in making investments are the benefits of investment, value added investment and economic conditions. The sample of this research is 96 students of Sharia Faculty and Islamic Economics IAIN Syekh Nurjati Cirebon.

The results of this study indicate that there is no relationship between the benefits of investment with the interest of investing in IAIN student Sheikh Nurjati Cirebon, evidenced by the value $(p=0.336>0.05)$. The results of the analysis also illustrates that there is no relationship between the added value and interest in investing in IAIN students Sheikh Nurjati Cirebon, as evidenced by value $(p=0.574>0.05)$. The variable of economic condition of student with investment interest in IAIN student Sheikh Nurjati Cirebon was also not related, proven based on the result $(p=0,619>0,05)$.

Investment for students is a learning process in order to prepare themselves in building economic life both personally and. The continuous improvement of socialization must continue to be done, because after all the capital market is one of the doors for students' learning process about economy and investment.

Keywords: Investment Benefits, Value Added, Economic Condition and Investment Interest and Capital Market

\section{Pendahuluan}

Individu yang telah mencukupi kebutuhan pokoknya, maka kegiatan ekonomi selanjutnya bertambah menjadi investasi. Ragam investasi ini bermacammacam diantaranya adalah tabungan, emas, tanah, sertifikat berharga (saham dan obligasi) dan lain-lain. Investasi bukan untuk dinikmati saat ini namun untuk masa yang akan datang. Investasi dapat diartikan sebagai penundaan konsumsi sekarang untuk digunakan di dalam produksi yang efisien selama periode waktu tertentu. ${ }^{1}$

Investasi di sektor pasar modal merupakan salah satu sumber alternatif pendanaan baik bagi pemerintah maupun swasta. Pemerintah yang membutuhkan dana dapat menerbitkan obligasi atau surat utang dan menjualnya ke masyarakat melalui pasar modal. Demikian juga swasta yang dalam hal ini adalah perusahaan yang membutuhkan dana dapat menerbitkan efek, baik dalam bentuk saham maupun obligasi dan menjualnya ke masyarakat melalui pasar modal. $^{2}$

\footnotetext{
1 Jogiyanto, Teori Portofolio dan Analisis Investasi; Edisi Ketiga, (Yogyakarta: BPFE, 2003), hlm. 5.

${ }^{2}$ Yenni Samri Juliati Nasution, Peranan Pasar Modal Dalam Perekonomian Negara,
}

Investasi di pasar modal juga merupakan alternatif investasi yang mudah diakses oleh masyarakat luas semenjak dibukanya Bursa Efek Indonesia (BEI). Namun aktivitas investasi ini masih merupakan hal yang relatif baru bagi masyarakat Indonesia jika dibandingkan dengan Negara lain, karena seperti yang dilansir dalam situs berita (tirto.id) Jumlah investor di pasar modal Indonesia memang belum menunjukkan peningkatan yang berarti, meski pasar modal Indonesia sudah berusia 25 tahun. Berdasarkan data Kustodian Sentral Efek Indonesia (KSEI), jumlah investor pasar modal Indonesia sampai dengan Maret 2018 mencapai 1,21 juta single investor identification (SID), naik 36 persen dari realisasi 2016 sebanyak 894.116 SID. Meski tumbuh dua digit, jumlah investor Indonesia relatif kecil jika dibandingkan dengan total penduduk 258 juta orang. Diadu dengan negara tetangga, Indonesia juga kalah dengan Malaysia dan Singapura yang memiliki 2,49 investor dan 1,5 juta investor. ${ }^{3}$

HUMAN FALAH, Vol. 2, No. 1, Januari-Juni 2015 hlm. 95-96.

${ }^{3}$ Ringkang Gumiwang, Tipisnya Jumlah Investor Pasar Modal Indonesia, diakses dari https://tirto.id/tipisnya-jumlah-investor-pasar- 
Saat ini pemerintah serius mengupayakan pengembangan industri pasar modal di Indonesia. Hal ini dibuktikan dengan program yang di selenggarakan oleh PT Bursa Efek Indonesia (BEI) melalui kampanye "Yuk Nabung Saham" guna mengajak masyarakat untuk mulai berinvestasi di pasar modal, dimulai dengan meningkatkan kesadaran masyarakat akan pentingnya berinvestasi saham yang selanjutnya dapat menaikkan jumlah investor local juga menyejahterakan perekonomian masyarakat Indonesia. Selain itu, untuk meningkatkan edukasi masyarakat tentang investasi dan memajukan pasar modal Indonesia, PT Bursa Efek Indonesia (BEI) bekerjasama dengan PT. Kliring Penjaminan Efek Indonesia (KPEI), PT Kustodian Sentral Efek Indonesia (KSEI), dan perusahaan-perusahaan sekuritas lain menyelenggarakan program edukasi lain seperti Sekolah Pasar Modal (SPM) kepada masyarakat guna menarik antusiasme masyarakat dalam mengenal investasi di pasar modal, baik di sektor saham maupun reksadana.

Berbagai program edukasi juga dilakukan kerjasama dengan institusi pendidikan yang bertujuan agar masyarakat dan mahasiswa lebih mengetahui tentang pasar modal, memahami pentingnya berinvestasi, mengenal saham sebagai alat investasi yang ideal, memahami kendalakendala sekaligus menarik minat masyarakat sebagai calon investor untuk berinvestasi di pasar modal Indonesia. ${ }^{4}$

Tidak bisa dipungkiri bahwa faktorfaktor yang mempengaruhi minat berinvestasi yaitu merupakan pengetahuan mengenai investasi itu sendiri. Mahasiswa sebagai agen of changetidak terkecuali mahasiswa IAIN Syekh Nurjati Cirebon,

modal-indonesia-cHXg pada tanggal 28 juni 2018

${ }^{4}$ Luh Komang Merawati, Kemampuan Pelatihan Pasar Modal Memoderasi Pengaruh Pengetahuan Investasi dan Penghasilan pada Minat Berinvestasi Mahasiswa, Jurnal Ilmiah Akuntansi dan Bisnis, Vol.10, No. 2, Juli 2015 : hlm.106 dalam banyak lini kehidupan masyarakat memiliki posisi strategis sebagai pelopor kemajuan ilmu pengetahuan, termasuk dalam mensosialisasikan dan menginformasikan tentanginvestasi di pasar modal. Secara perlahan pasar modal akanterus mengalami perkembangan yang cukup signifikan. Dalam konteks perkembangan ekonomi Indonesia, mahasiswa memiliki peran sangat penting khususnya mahasiswa di bidang studi ekonomi dan bisnis yang telah dibekali dasar pengetahuan investasi dalam perkuliahannya. Mahasiswa diharapkan mampu menjadi salah satu calon investor muda ideal dan berkontribusi aktif memajukan serta meningkatkan investasi di pasar modal Indonesia.

Investasi pada pasar modal terutama pada investasi saham mempunyai keunggulan, yaitu akan memperoleh return yang berasal dari capital gain dan deviden. Deviden yang diperoleh oleh seorang investor ditentukan oleh kemampuan perusahaan dalam memperoleh laba. Return yang berasal dari capitalgain yang diperoleh, juga dipengaruhi oleh fluktuasi harga saham. Kemampuan perusahaan memperoleh laba dipengaruhi oleh faktor mikro dan makro yang pada gilirannya akan berpengaruh terhadap fluktuasi harga saham. Kedua faktor tersebut akan mempengaruhi risiko investasi saham. ${ }^{5}$

Berbagai hasil penelitian mengenai minat mahasiswa untuk berinvestasi di pasar modal dinilai masih variatif; antara lainberdasarkan hasil analaisis asumsi klasik dan analaisis regresi linier sederhana yang dilakukan oleh Rizki Chaerul Pajar ${ }^{6}$ membuktikan bahwa motivasi investasi dan pengetahuan tentang investasi dapat mempengaruhi minat mahasiswa FE UNY

5 Erna R. Rahadjeng, Analisis Perilaku Investor Perspektif Gender dalam Pengambilan Keputusan Investasi di Pasar Modal, HUMANITY, Jurnal Ekonomi Islam, Vol. 6, No. 2, Maret 2011: hlm. $90-97$

6 Rizki Chaerul Pajar, Pengaruh Motivasi Investasi dan Pengetahuan Investasi terhadap Minat Investasi di Pasar Modal pada Mahasiswa FE UNY, Jurnal Profita Edisi 1, 2017 : hlm. 12 
untuk berinvestasi di pasar modal. Sementara itu menurut Daniel Raditya, $\mathrm{dkk}^{7}$ menjelaskan dalam tulisannya bahwa modal investasi minimal tidak berpengaruh terhadap minat investasi, sedangkan persepsi terhadap risiko dan return berpengaruh terhadap minat investasi, serta penghasilan tidak dapat memoderasi hubungan modal investasi minimal dengan minat investasi, return dengan minat investasi, serta persepsi terhadap resiko dengan minat investasi.

Pada penelitian tentang minat pasar modal lainyayang dilakukan olehTandio dan Widanaputra ${ }^{8}$ menggunakan metode kualitatif dikonversi dengan aplikasi MSI atau Method of Successive Interval,menyatakanbahwa pelatihan pasar modal dan risiko berpengaruh pada minat investasi secara signifikan. Kemudian untuk variable persepsi risiko, gender serta kemajuan teknologi tidak berpengaruh terhadap minat mahasiswa untuk berinvestasi secara signifikan.

Demikian berdasarkan hasil studi yang dilakukan oleh Arlin Ferlina ${ }^{9}$ bahwa secara simultan informasi produk, risiko investasi dan kepuasan investor berpengaruh terhadap minat mahasiswa berinvestasi saham.Adapun menuruttulisan penelitian yang dilakukan oleh Luh Komang dan Mega Putra $^{10}$ menunjukkan adanyapengaruh positif

7 Daniel Raditya, dkk.,Pengaruh Modal Investasi Minimal di BNI Sekuritas, Return dan Persepsi terhadap Risiko pada Minat Investasi Mahasiswa, dengan Penghasilan sebagai Variabel Moderasi, E-Jurnal Ekonomi dan Bisnis Universitas Udayana, 2014, hlm. 386.

8 Timothius Tandio dan A.A.G.P Widanaputra, Pengaruh Pelatihan Pasar Modal, Return, Persepsi Risiko, Gender dan Kemajuan Teknologi pada Minat Investasi Mahasiswa, ejurnal Akuntansi Universitas Udayana, Vol.16, No.3, September 2016 : hlm. 2339

9 Arlin Ferlina Mochammad Trenggana, Riswan Kuswardhana, Pengaruh Informasi Produk, Risiko Investasi, Kepuasaan Investor dan Minat Mahasiswa Berinvestasi, JSAB, Jurnal Sekretaris dan Administrasi Bisnis, Vol.1, No. 1, Agustus 2017 : hlm.16

10 Luh Komang Merawati, Kemampuan Pelatihan Pasar Modal Memoderasi Pengaruh Pengetahuan Investasi dan Penghasilan pada signifikan pada pengetahuan investasi dan pendapatan terhadap minat mahasiswa untuk menanamkan modalnya di pasar modal.

$$
\text { Menurut Hermanto }{ }^{11} \text { dalam }
$$

tulisannya ditemukan hasil pengujian hipotesis statistikyang didapat dengan menggunakan regresi linier berganda menunjukkan bahwa manfaat investasi serta return investasi berpengaruh positif terhadap minat investasi. Sementara itu edukasi, modal minimum dan motivasi tidak berpengaruh terhadap minat mahasiswa untuk berinvestasi.Sedangkan berdasarkan hasil studi Nurul Hayati 12 dengan menggunakan regresi linier berganda, menunjukan bahwa earning per share, return on assets, return on equity, debt equity ratio berpengaruh terhadap price earning ratio perusahaan real estate dan property yang terdaftar di Bursa Efek Indonesia.

\section{Pengertian Pasar odal}

Pasar modal berdasarkan UndangUndang Pasar Modal (UUPM) no.8 tahun 1995 Pasal 1 Nomor 13 menjelaskan, pasar modal adalah kegiatan yang bersangkutan dengan penawaran umum dan perdagangan efek, perusahaan publik yang berkaitan dengan efek yang diterbitkannya, serta lembaga dan profesi yang berkaitan dengan efek. Dalam UUPM tersebut tidak dipisahkan antara pasar modal syariah dengan pasar modal konvensional. Pasar modal mempunyai peran penting sebagai sarana investasi jangka panjang dalam

Minat Berinvestasi Mahasiswa, Jurnal IImiah Akuntansi dan Bisnis, Vol.10, No. 2, Juli 2015 : hlm.112

${ }^{21}$ Hermanto, Perilaku Mahasiswa Ekonomi di Universitas Esa Unggul dalam Melakukan Investasi di Pasar Modal, Jurnal Ekonomi, Vol.8, No.2, Mei 2017 : hlm. 15

${ }_{12}$ Nurul Hayati, Faktor-faktor yang Mempengaruhi Price Earning Ratio (PER) sebagai Salah Satu Kriteria Keputusan Investasi Saham Perusahaan Real Estate dan Property di Bursa Efek Indonesia, Vol. 11, No. 1, April 2010 : hlm. 8 
perekonomian. ${ }^{13}$ Pasar modal Indonesia berada di bawah naungan Otoritas Jasa Keuangan (OJK). Sebagaimana menurut Yenni Samri Juliati Nasution dalam tulisannya menjelaskanlembaga-lembaga yang terlibat di pasar modal adalah meliputi $:^{14}$

1. Perusahaan Emiten

Adalah perusahaan yang akan melakukan penjualan surat-surat berharga.

2. Investor

Merupakan penanam modal yang akan membeli atau menanamkan modalnya di perusahaan yang melakukan emisi. Sebelum membeli surat berharga yang ditawarkan investor harus melakukan penelitian dan analisis tertentu.

3. Bank Kustodian

Bank yang merupakan tempat menyimpan modal investor yang akan dikelola oleh perusahaan emiten.

4. Lembaga penunjang

Lembaga penunjang yang dimaksud adalah meliputi; Penjamin emisi (underwriter), perantara pedagang efek (broker/pialang), pedagang efek (dealer), penanggung (buarantor), wali amanat (trustee).

\section{Instrumen Utama Pasar Modal}

Adapun masing-masing jenis instrumen utama pada pasar modal adalah antara lain;

1. Saham (Stock)

Merupakan surat berharga yang bersifat kepemilikan, artinya pemilik saham merupakan pemilik perusahaan. Semakin besar saham yang dimilikinya, maka semakin besar pula kekuasaannya di perusahaan tersebut. Keuntungan

\footnotetext{
${ }^{13}$ Anna Nurlita, Investasi di Pasar Modal Syariah dalam Kajian Islam, Jurnal Penelitian Sosial Keagamaan. Vol 17.No. 1 Januari-Juni, 2014, hIm. 2.

${ }^{14}$ Yenni Samri Juliati Nasution, Peranan Pasar Modal Dalam Perekonomian Negara, HUMAN FALAH, Vol. 2, No. 1, Januari-Juni 2015 hlm. 106-108.
}

yang diperoleh dari saham dikenal dengan nama deviden. ${ }^{15}$

2. Surat berharga obligasi merupakan instrument uutang bagi perusahaan yang hendak memperoleh modal. Obligasi secara ringkasnya adalah utang tetapi dalam bentuk sekuriti. "penerbit' obligasi adalah sipeminjam ataupun debitur. Sedangkan "pemegang" obligasi adalah pemberi pinjaman atau kreditur dan "kupon" obligasi adalah bunga pinjaman yang harus dibayar oleh debitur kepada kreditur. Dengan penerbitan obligasi ini maka dimungkinkan bagi penerbit obligasi guna memperoleh pembayaran investasi jangka panjangnya dengan sumber dana dari luar perusahaan. ${ }^{16}$

\section{Minat Investasi}

Minat dalam Kamus Besar Bahasa Indonesia (KBBI) diartikan sebagai kecenderungan hati yang tinggi terhadap sesuatu gairah ataupun keinginan. ${ }^{17}$ Sementara menurut Lilis 18 dalam tulisannyamenyatakan bahwa minat merupakan fungsi kejiwaan atau sambutan yang sadar untuk tertarik terhadap suatu objek baik berupa benda atau yang lain. Selain itu minat dapat timbul karena ada gaya tarik dari luar dan juga datang dari hati sanubari. Minat yang besar terhadap suatu hal merupakan modal besar untuk mencapai tujuan yang diminati dalam hal ini berinvestasi terutama di sektor pasar modal. Dalam penelitianya dikatakan juga bahwa indikator dari seseorang berminat atau tidak maka dibutuhkan deskripsi yang jelas

\footnotetext{
${ }^{15}$ Kasmir, Bank dan Lembaga keuangan
} Lainnya,( Jakarta : Rajawali Press, 2009), hlm. 209.

16 Yenni Samri Juliati Nasution, Peranan Pasar Modal Dalam Perekonomian Negara, HUMAN FALAH, Vol. 2, No. 1, Januari-Juni 2015 hlm. 106.

17 Anton Moeliono, dkk, Kamus Besar Bahasa Indonesia, (Jakarta: Balai Pustaka, 1999), hlm. 225.

${ }_{18}$ Lilis Yuliati, Faktor-faktor yang Mempengaruhi Minat Masyarakat Berinvestasi Sukuk, Walisongo, Vol 19, No 1 Mei 2011, hlm. $110-111$. 
mengenai keberminatan seseorang, hal ini bisa kita lihat dari keaktifan seseorang dalam mencari informasi, mengidentifikasi semua persoalan yang di minati, menganalisis, dan membuat daftar table tentang sesuatu yang di minati hingga penetapan bidang yang di minati.

Dalam sistem ekonomi konvensional, seseorang melakukan investasi dengan motif yang berbeda-beda, salah satunya adalah untuk memenuhi kebutuhan likuiditas, menabung dengan tujuan mendapatkan pengembalian yang lebih besar, merencanakan pensiun dan bahkan untuk berspekulasi. $^{19}$

\section{Faktor-Faktor Yang Mempengaruhi Minat Investasi}

Menurut Daniel Raditya $\quad{ }^{20}{ }^{20}$ dalam tulisannya menjelaskan beberapa faktorfaktor yang berpengaruh terhadap minat berinvestasi,adalah antara lain:

1. Neutralinformation, adalah informasi yang berasal dari luar, memberikan informasi tambahan agar informasi yang dimiliki oleh calon investor menjadi lebih komprehensif.

2. Personalfinancialneeds, adalah informasi pribadi yang diperoleh selama investor tersebut berkecimpung dalam dunia investasi yang dapat menjadi semacam pedoman bagi investor tersebut dalam investasi berikutnya.

3. Self imagelfirm image coincidence, adalah informasi yang berhubungan dengan peniliaian terhadap citra perusahaan.

4. Socialrelevance, adalah informasi yang menyangkut posisi saham perusahaan di bursa, tanggung jawab perusahaan terhadap lingkungan

19 Anna Nurlita, Investasi di Pasar Modal Syariah dalam Kajian Islam, Jurnal Penelitian Sosial Keagamaan. Vol 17.No. 1 Januari-Juni, 2014, hlm. 15.

20 Daniel Raditya, dkk, Pengaruh Modal Investasi Minimal di BNI Sekuritas, Return dan Persepsi terhadap Risiko pada Minat Investasi Mahasiswa, dengan Penghasilan sebagai Variabel Moderasi, E-Jurnal Ekonomi dan Bisnis Universitas Udayana, 2014, hlm. 381. sekitar serta area operasional perusahaan, nasional atau internasional.

5. Classic, merupakan kemampuan investor untuk menentukan kriteria ekonomis perilaku.

6. Professional recommendation, merupakan pendapat, saran, atau rekomendasi dari pihak-pihak, saran, atau rekomendasi dari pihak-pihak, professional atau para ahli di bidang investasi.

\section{Dasar Keputusan Untuk Melakukan Investasi}

Dasar keputusan investasi terdiri dari tingkat return harapan, tingkat risiko serta hubungan antara return dan risiko. Berikut ini akan dibahas masing-masing dasar keputusan investasi tersebut. Diantaranya: ${ }^{21}$

1. Return adalah alasan utama orang berinvestasi adalah untuk memperoleh keuntungan. Dalam konteks manajemen investasi tingkat keuntungan investasi disebut sebagai return suatu hal yang sangat wajar jika investor menuntut tingkat return tertentu atas dana yang telah diinvestasikannya.

2. Memiliki Risiko yang tidak terlalu besar, karena sudah sewajarnya jika investor mengharapkan return yang setinggitingginya dari investasi yang dilakukannya. Tetapi ada hal penting yang harus selalu dipertimbangkan, yaitu berapa besar risiko yang harus ditanggung dari investasi tersebut. Umumnya semakin besar risiko, maka semakin besar pula tingkat return harapan.

\section{Metodologi Penelitian Jenis Penelitian}

Penelitian yang dilakukan merupakan penelitian deskriptif, dimana peneliti menggali suatu fenomena tertentu dengan mengkaji objek tertentu, sehingga hasil penelitian hanya dapat diimplementasikan

${ }^{21}$ Hermanto, Perilaku Mahasiswa Ekonomi di Universitas Esa Unggul dalam Melakukan Investasi di Pasar Modal, Jurnal Ekonomi, Vol.8, No.2, Mei 2017 : hlm. 4. 
pada objek penelitian saja dan bertujuan untuk mengambarkan secara tepat dan sistematis terhadap fenomena yang sedang diteliti.

Pengumpulan data dilakukan dengan pengambilan jawaban responden melalui kuesioner dan wawancara. Kuesinonerterbuka dipersepsikan dengan metode kualitatif. Seperti halnya menurut Moleong dalam Yanuar $\operatorname{Ikbar}^{22}$ menjabarkan sebelas karakteristik pendekatan kualitatif salah satunya adalah menggunaka manusia sebagai instrumen utama dalam penelitian, dalam penelitian ini mahasiswa sebagai instrumen partama kajian.

\section{Jenis dan Sumber Data}

Jenis data penelitian ini adalah subyek penelitian, artinya data merupakan pendapat dan opini dari beberapa sampel yang dalam hal ini adalah mahasiswa FSEI Iain Syekh Nurjati Cirebon. Sumber data yang digunakan dalam penelitian ini adalah data primer, dimana data primer dikumpulkan dari sumber-sumber langsung yaitu mahasiswa. Data-data yang dibutuhkan adalah: identifikasi data umum mahasiswa meliputi alamat, umur dan jenis kelamin; faktor-faktor yang mempengaruhi keinginan dalam mengambil keputusan untuk berinvestasi di pasar modal. Data diperoleh langsung dari mahasiswa aktif di FSEI Iain Syekh Nurjati Cirebon.

\section{Pendekatan Penelitian}

Dalam menjawab permasalahan tersebut, maka metode penelitian yang dipakai adalah menggunakan metode mixed methods. Menurut Rully Indrawan dan Poppy Yaniawati $^{23}$ pendekatan campuran (Mixed Methods) adalah menggabungkan berbagai metode baik kualitatif maupun kuantitatif pada sebuah penelitian. Penelitian ini juga menggunakan kuesioner dan interview, yaitu pengumpulan data yang dilakukan dengan memberikan pertanyaan secara tertulis maupun pertanyaan langsung

${ }^{22}$ Yanuar Ikbar, Metode Penelitian Sosial Kualitatif:;Cetakan Kesatu, (Bandung; Refika Aditama, 2012), hlm. 123.

${ }^{23}$ Rully Indrawan dan Poppy Yaniawati., Metodologi Penelitian, (Bandung; Refika Aditama, 2014), hlm.76. kepada responden. Dalam mengumpulkan data dengan kuesioner digunakan skala Likert, dengan skor 5,4,3,2, dan 1 .

\section{Hasil dan Pembahasan}

Pada Penelitian ini, penulis mencoba membagi dalam beberapa atribut penelitian, meliputi variable dependen dan variabel independen. Variabel Dependen (terikat) adalah minat Mahasiswa untuk melakukan investasi di pasar modal, sementara variabel yang mempengaruhinya adalah ; Manfaat investasi, nilai tambah dan yang terakhir adalahkondisi ekonomi keluarga mahasiswa.

\section{Identitas Responden}

Tabel 1 .Jenis Kelamin Responden

\begin{tabular}{ccc}
\hline Keterangan & Frekuensi & Persen \\
\hline Laki-laki & 27 & 28,1 \\
Perempuan & 69 & 71,9 \\
\hline Jumlah & 96 & 100 \\
\hline
\end{tabular}

Tabel 2. Asal Kelas Responden

\begin{tabular}{ccc}
\hline Kelas & Frekuensi & Persen \\
\hline A & 33 & 34 \\
B & 29 & 30 \\
C & 34 & 35 \\
\hline Jumlah & 96 & 100 \\
\hline
\end{tabular}

Dari Tabel 1 dan 2 memperlihatkan bahwa responden perempuan mendominasi dengan jumlah $69(71,9 \%)$ responden, sementara responden laki-laki berjumlah $27(28,1 \%)$. Sementara asal kelas mahasiswa yang menjadi responden adalah dari kelas A berjumlah 33 (34\%), dari kelas B berjumlah 29 (30\%), dan kelas C sebanyak 34 (35\%) mahasiswa. 


\section{Distribusi Frekuensi Minat Investasi, Manfaat Investasi, Nilai Tambah Investasi dan Kondisi Ekonomi}

Tabel 3. Keterminatan Investasi di Pasar Modal

\begin{tabular}{|c|c|c|c|c|c|c|}
\hline Kriteria & SM & M & $\mathbf{C M}$ & TM & STM & jumlah \\
\hline \multirow{2}{*}{ Keterminatan informasi untuk investasi } & 27 & 41 & 28 & 0 & 0 & 96 \\
\hline & $28 \%$ & $43 \%$ & $29 \%$ & $0 \%$ & $0 \%$ & $100 \%$ \\
\hline \multicolumn{7}{|l|}{ Keterminatan Informasi investasi di } \\
\hline \multirow[t]{2}{*}{ Pasar Modal } & 26 & 42 & 28 & 0 & 0 & 96 \\
\hline & $27 \%$ & $44 \%$ & $29 \%$ & $0 \%$ & $0 \%$ & $100 \%$ \\
\hline \multirow[t]{2}{*}{$\begin{array}{l}\text { Keterminatandalam mengakses dan } \\
\text { melakukan Investasi }\end{array}$} & 27 & 41 & 28 & 0 & 0 & 96 \\
\hline & $28 \%$ & $43 \%$ & $29 \%$ & $0 \%$ & $0 \%$ & $100 \%$ \\
\hline \multirow[t]{2}{*}{$\begin{array}{l}\text { Keterminatan dalam Mengakses dan } \\
\text { melakukan Investasi di Pasar Modal }\end{array}$} & 24 & 43 & 28 & 1 & 0 & 96 \\
\hline & $25 \%$ & $45 \%$ & $29 \%$ & $1 \%$ & $0 \%$ & $100 \%$ \\
\hline
\end{tabular}

\section{Hasil Survey, 2018}

Berdasarkan pada Tabel 3 dari 96 responden, didapatkan penilaian mahasiswa IAIN Syekh Nurjati Cirebon terhadap minat mahasiswa untuk berinvestasi di pasar modal (variabel dependen) dengan kriteria keterminatan terhadap informasi investasi sebagian besar mahasiswa menyatakan Setuju yaitu sebanyak 41 (43\%) responden. Sementara itu keterminatan terhadap informasi investasi di pasar modal, sebagian besar mahasiswa menyatakan Setuju yaitu sebanyak $42 \quad(44 \%)$ responden. Adapun kriteria keterminatan dalam mengakses dan melakukan investasi sebagian besar mahasiswa menyatakan Setuju yaitu sebanyak 41 (43\%) responden dan keterminatan dalam mengakses dan melakukan investasi di pasar modal sebagian besar mahasiswa juga menyatakan Setuju yaitu sebanyak $43(45 \%)$ responden.

Tabel 4. Manfaat Investasi di Pasar Modal

\begin{tabular}{lrrrrrr}
\hline Kriteria & s & s & cs & ts & sts & jumlah \\
\hline Meningkatkan kesejahteraan & 30 & 45 & 21 & 0 & 0 & 96 \\
& $31 \%$ & $47 \%$ & $22 \%$ & $0 \%$ & $0 \%$ & $100 \%$ \\
PM pilihan cocok untuk investasi & 32 & 44 & 20 & 0 & 0 & 96 \\
& $33 \%$ & $46 \%$ & $21 \%$ & $0 \%$ & $0 \%$ & $100 \%$ \\
Manfaat dimasa mendatang & 32 & 45 & 19 & 0 & 0 & 96 \\
& $33 \%$ & $47 \%$ & $20 \%$ & $0 \%$ & $0 \%$ & $100 \%$ \\
Mendapatkan penghasilan tambahan & 31 & 45 & 20 & 0 & 0 & 96 \\
& $32 \%$ & $47 \%$ & $21 \%$ & $0 \%$ & $0 \%$ & $100 \%$ \\
\hline
\end{tabular}

\section{Hasil Survey, 2018}

Berdasarkan Tabel 4 diatas dari 96 responden, didapatkan penilaian mahasiswa IAIN Syekh Nurjati Cirebon terhadap manfaat mahasiswa untuk berinvestasi di pasar modal dengan kriteria meningkatkan kesejahteraan sebagian besar mahasiswa menyatakan Setuju yaitu sebanyak 45 (47\%) responden. Sementara itu manfaat investasi pasar modal merupakan pilihan yang cocok untuk investasi, sebagian besar mahasiswa menyatakan Setuju yaitu sebanyak 44 (46\%) responden. Adapun kriteria manfaat investasi 
dimasa mendatang sebagian besar mahasiswa menyatakan Setuju yaitu sebanyak 45 (47\%) responden. Demikian halnya manfaat investasi untuk mendapatkan penghasilan tambahan, sebagian besar mahasiswa juga menyatakan Setuju yaitu sebanyak 45 (47\%) responden.

Tabel 5. Nilai Tambah Investasi di Pasar Modal

\begin{tabular}{lrrrrrr}
\hline Kriteria & \multicolumn{1}{c}{ ss } & \multicolumn{1}{c}{ s } & \multicolumn{1}{c}{ cs } & sts & jumlah \\
\hline Pasar Modal memberikan nilai tambah & 26 & 48 & 22 & 0 & 0 & 96 \\
& $27 \%$ & $50 \%$ & $23 \%$ & $0 \%$ & $0 \%$ & $100 \%$ \\
Pasar Modal memberikan keuntungan & & & & & & \\
sesuai resiko & 27 & 48 & 21 & 0 & 0 & 96 \\
& $28 \%$ & $50 \%$ & $22 \%$ & $0 \%$ & $0 \%$ & $100 \%$ \\
Keuntungan Pasar Modal melebihi & & & & & & \\
tabungan. Biasa & 29 & 48 & 19 & 0 & 0 & 96 \\
& $30 \%$ & $50 \%$ & $20 \%$ & $0 \%$ & $0 \%$ & $100 \%$ \\
Hampir tidak ada kerugian investasi di PM & 28 & 48 & 20 & 0 & 0 & 96 \\
& $29 \%$ & $50 \%$ & $21 \%$ & $0 \%$ & $0 \%$ & $100 \%$ \\
\hline
\end{tabular}

Hasil Survey, 2018

Berdasarkan Tabel 5 diatas, dari 96 responden didapatkan penilaian mahasiswa IAIN Syekh Nurjati Cirebon terhadap nilai tambah yang didapat dari pasar modal sebagai memperlihatkan mahasiswa menyatakan Setuju yaitu sebanyak 48 (50\%) responden. Adapun kriteri pasar modal memberikan keuntungan sesuai resiko, sebagian besar mahasiswa menyatakan
Setuju yaitu sebanyak 48 (50\%) responden. Sama halnya dengan keuntungan pasar modal yang dapat melebihi tabungan biasa, sebagian besar mahasiswa menyatakan Setuju yaitu sebanyak 48 (50\%) responden, dan nilai tambah investasi di pasar modal yang hamper tidak terdapat kerugian, sebagian besar mahasiswa juga menyatakan Setuju yaitu sebanyak 48 (50\%) responden.

Tabel 6. Kondisi Ekonomi Mahasiswa

\begin{tabular}{lrrrrrr}
\hline Kriteria & ss & \multicolumn{1}{c}{ s } & \multicolumn{1}{c}{ cs } & \multicolumn{1}{c}{ ts } & \multicolumn{1}{c}{ sts } & jumlah \\
\hline Kondisi eko mendukung investasi & 19 & 44 & 33 & 0 & 0 & 96 \\
& $20 \%$ & $46 \%$ & $34 \%$ & $0 \%$ & $0 \%$ & $100 \%$ \\
Keluarga mendukung investasi & 19 & 45 & 32 & 0 & 0 & 96 \\
& $20 \%$ & $47 \%$ & $33 \%$ & $0 \%$ & $0 \%$ & $100 \%$ \\
Uang saku yang cukup & 21 & 44 & 31 & 0 & 0 & 96 \\
Kondisi ekonomi tdk terganggu & $22 \%$ & $46 \%$ & $32 \%$ & $0 \%$ & $0 \%$ & $100 \%$ \\
& 21 & 43 & 32 & 0 & 0 & 96 \\
& $22 \%$ & $45 \%$ & $33 \%$ & $0 \%$ & $0 \%$ & $100 \%$ \\
\hline
\end{tabular}

\section{Hasil Survey, 2018}

Berdasarkan Tabel 6 diatas dari 96 responden, didapatkan penilaian mahasiswa IAIN Syekh Nurjati Cirebon terhadap aspek kondisi ekonomi mahasiswa dengan kriteria kondisi ekonomi mendukung untuk berinvestasi sebagian besar mahasiswa menyatakan Setuju yaitu sebanyak 44 (46\%) responden. Sementara itu kondisi ekonomi mahasiswa selaku responden dengan kriteria keluarga mendukung berinvestasi, sebagian besar mahasiswa menyatakan Setuju yaitu sebanyak $45(47 \%)$ responden. Adapun kriteria uang saku yang cukup sebagian besar mahasiswa menyatakan Setuju yaitu 
sebanyak $44(46 \%)$ responden, dan dalam kriteria kondisi ekonomi mahasiswa yang tidak terganggu sebagian besar mahasiswa juga menyatakan Setuju yaitu sebanyak 43 $(45 \%)$ responden.

3. Hubungan Antara Manfaat Investasi, Nilai Tambah, Kondisi Ekonomi Terhadap Minat Investasi

Tabel 7. Hubungan antara manfaat investasi, nilai tambah dan kondisi ekonomi terhadap minat Investasi mahasiswa IAIN Syekh Nurjati Cirebon di Pasar Modal

\begin{tabular}{|c|c|c|c|c|c|c|c|}
\hline \multirow{3}{*}{ Variabel } & \multicolumn{4}{|c|}{ Minat Investasi } & \multirow{2}{*}{\multicolumn{2}{|c|}{ Jumlah }} & \multirow{3}{*}{$\mathrm{P}$} \\
\hline & \multicolumn{2}{|c|}{$\begin{array}{l}\text { Tidak } \\
\text { minat }\end{array}$} & \multicolumn{2}{|c|}{ Minat } & & & \\
\hline & $\mathrm{n}$ & $\%$ & $\mathrm{n}$ & $\%$ & $\mathrm{n}$ & $\%$ & \\
\hline \multicolumn{8}{|c|}{ Manfaat investasi } \\
\hline Tidak setuju & 48 & 75 & 16 & 25 & 64 & 100 & 0,336 \\
\hline Setuju & 21 & 65,6 & 11 & 34.4 & 32 & 100 & \\
\hline \multicolumn{8}{|l|}{ Nilai Tambah } \\
\hline Tidak setuju & 50 & 73,5 & 18 & 26,5 & 68 & 100 & 0,574 \\
\hline Setuju & 19 & 67,9 & 9 & 32.1 & 28 & 100 & \\
\hline \multicolumn{8}{|c|}{ Kondisi Ekonomi } \\
\hline Tidak setuju & 53 & 70,7 & 22 & 29,3 & 75 & 100 & 0,619 \\
\hline Setuju & 16 & 76,2 & 5 & 23.8 & 21 & 100 & \\
\hline
\end{tabular}

Berdasarkan tabel 7 dari 96 reponden, didapatkan responden yang menyatakan manfaat investasi tidak setuju serta tidak minat investasi sebesar $48 \quad(75 \%)$ dan reponden yang menyatakan setuju serta tidak minat investasi sebesar $21 \quad(65,6 \%)$. Berdasarkan hasil uji korelasi di peroleh $\mathrm{p}=$ 0.336 lebih besar dari 0.05 artinya tidak ada hubungan antara manfaat investasi dengan minat mahasiswa untuk berinvestasi di pasar modal.

Tidak adanya hubungan antara manfaat dan minat untuk berinvestasi dimungkinkan karena beberapa hal, salah satu yang mengemuka adalah mahasiswa sebenarnya mengetahui manfaat investasi, namun keterbatasan informasi yang ada dikampus tentang peluang investasi di pasar modal membuat mahasiswa tetap tidak berminat untuk berinvestasi di pasar modal.

Pada aspek nilai tambah, berdasarkan tabel 7 dari 96 reponden didapatkan responden yang menyatakan tidak setuju terhadap nilai tambah serta tidak minat investasi sebesar 50 (75\%) dan reponden yang menyatakan setuju terhadap nilai tambah tapi tidak minat investasi sebesar 19 $(67,9 \%)$. Berdasarkan hasil uji korelasi di peroleh $\mathrm{p}=0.574$ lebih besar dari 0.05 artinya tidak ada hubungan antara nilai tambah investasi dengan minat mahasiswa untuk berinvestasi di pasar modal. Karena pengetahuan tentang seluk beluk pasar modal yang sangat terbatas, apalagi tentang return dan capitalgain sebagai bagian dari nilai tambah dipasar modal menyebabkan mahasiswa kurang tertarik untuk berinvestasi di pasar modal.

Pada aspek kondisi ekonomi Berdasarkan tabel 7 dari 96 reponden didapatkan responden yang menyatakan tidak setuju terhadap kondisi ekonomi serta tidak minat investasi sebesar $53(70,7 \%)$ dan reponden yang menyatakan setuju terhadap Kondisi ekonomi tapi tidak minat investasi sebesar 22 (29,3\%). Kondisi ekonomi mahasiswa Iain Syekh Nurjati Cirebon sangat bervariasi, namun yang beruntung secara ekonomipun belum tertarik untuk berinvestasi di pasar modal. 


\section{Penutup}

Berdasarkan hasil dan pembahasan dalam penelitian tentang minat mahasiswa IAIN Syekh Nurjati Cirebon dalam investasi di pasar modal, dapat disimpulkan sebagai berikut;

1. Tidak ada hubungan atas manfaat investasi dengan minat berinvestasi pada mahasiswa IAIN Syekh Nurjati Cirebon. Hal tersebut dibuktikan berdasarkan nilai $p$ value yang di peroleh 0.336 lebih besar dari 0.05. Dapat diartikan bahwa walaupun ada kepahaman tentang manfaat investasi di pasar modal namun tidak sampai menggugah minat mahasiswa untuk melakukan investasi di pasar modal.

2. Tidak ada hubungan antara nilai tambah dan minat berinvestasi pada mahasiswa IAIN Syekh Nurjati Cirebon. Hal tersebut dibuktikan berdasarkan hasil nilai $p$ value yang di peroleh 0.574 tidak lebih kecil dari 0.05. Dapat diartikan bahwa dalam beberapa hal sebenarnya mahasiswa juga mengerti dan mengetahui nilai tambah investasi di pasar modal, namun tidak sampai memberikan dorongan mahasiswa untuk segera berinvestasi di pasar modal.

3. Tidak ada hubungan antara kondisi ekonomi mahasiswa dengan minat investasi pada mahasiswa IAIN Syekh Nurjati Cirebon. Hal tersebut dapat dibuktikan berdasarkan nilai $p$ value yang di peroleh0,619lebih besar dari 0.05. Dapat dijelaskan bahwa memang kondisi ekonomi mahasiswa tidak memiliki hubungan dengan minat investasi mahasiswa. Secara faktual menerangkan dan menggambarkan kondisi ekonomi mahasiswa IAIN Syekh Nurjati Cirebon .

\section{Daftar Pustaka}

Ferlina Arlin.2017. Pengaruh Informasi Produk, Risiko Investasi, Kepuasaan Investor dan Minat
Mahasiswa Berinvestasi.JSAB; Jurnal Sekretaris dan Administrasi Bisnis, Vol. 1, No. 1.

Gumiwang, Ringkang. Tipisnya Jumlah Investor Pasar Modal Indonesia. diakses dari https://tirto.id/tipisnyajumlah-investor-pasar-modalindonesia-cHXg pada tanggal 28 juni 2018.

Hermanto. 2017. Perilaku Mahasiswa Ekonomi di Universitas Esa Unggul dalam Melakukan Investasi di Pasar Modal. Jurnal Ekonomi, Vol. 8, No. 2.

Ikbar, Yanuar. 2012. Metode Penelitian Sosial Kualitatif; Edisi Kesatu. Bandung: Refika Aditama.

Indrawan, Rully dan Yaniawati, Poppy. 2014. Metodologi Penelitian. Bandung: Refika Aditama.

Jogiyanto. 2003. Teori Portofolio dan Analisis Investasi; Edisi Ketiga. Yogyakarta: BPFE.

Kasmir. 2009. Bank dan Lembaga keuangan Lainnya. Jakarta : Rajawali Press.

Merawati, Luh Komang.2015. Kemampuan Pelatihan Pasar Modal Memoderasi Pengaruh Pengetahuan Investasi dan Penghasilan pada Minat Berinvestasi Mahasiswa. Jurnal Ilmiah Akuntansi dan Bisnis. Vol. 10, No. 2.

Moeliono, Anton.dkk. 1999. Kamus Besar Bahasa Indonesia. Jakarta: Balai Pustaka.

Nasution, Yenni S.J. 2015. Peranan Pasar Modal Dalam Perekonomian Negara. HUMAN FALAH. Vol. 2, No. 1.

Nurlita, Anna. 2014. Investasi di Pasar Modal Syariah dalam Kajian Islam, Jurnal Penelitian Sosial Keagamaan. Vol 17.No. 1.

Pajar, Rizki Chaerul. 2017. Pengaruh Motivasi Investasi dan Pengetahuan Investasi terhadap Minat Investasi di Pasar Modal pada Mahasiswa FE UNY. Jurnal Profita Edisi 1.

Raditya, Daniel.,dkk.2014. Pengaruh Modal Investasi Minimal di BNI Sekuritas, 
Return dan Persepsi terhadap Risiko pada Minat Investasi Mahasiswa, dengan Penghasilan sebagai Variabel Moderasi. EJurnal Ekonomi dan Bisnis Universitas Udayana.

Rahadjeng, Erna R. 2011. Analisis Perilaku Investor Perspektif Gender dalam Pengambilan Keputusan Investasi di Pasar Modal. HUMANITY;Jurnal Ekonomi Islam, Vol. 6, No. 2

Tandio, Timothius. 2016. Pengaruh Pelatihan Pasar Modal, Return, Persepsi Risiko, Gender dan Kemajuan Teknologi pada Minat Investasi Mahasiswa. e-jurnal Akuntansi Universitas Udayana. Vol.16, No. 3.

Yuliati, Lilis. 2011. Faktor-faktor yang Mempengaruhi Minat Masyarakat Berinvestasi Sukuk. Walisongo, Vol.19, No. 1. 